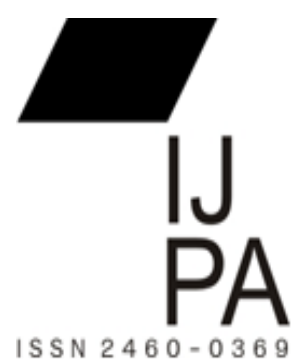

ISSN $2460-0369$

\title{
PROBLEMATIKA PENGELOLAAN SAMPAH DAERAH KHUSUS IBUKOTA JAKARTA
}

\author{
Adi Saputro \\ Mahasiswa Program Studi Ilmu Administrasi Publik \\ Universitas 17 Agustus 1945 Jakarta \\ adiplutonium@gmail.com
}

\begin{abstract}
The issue of waste is now an issue that requires more attention for the world. How not today's garbage becomes the biggest contributor to environmental damage to the world. With this, solutions are needed to solve the problem of waste that becomes environmental damage, one of which is by doing waste management again in order to reduce environmental damage. As is done in Indonesia, especially in DKI Jakarta Province which should do good waste management in order to reduce environmental damage that will impact people's lives such as flood disasters and so on. In this study discussed how the role of the DKI Jakarta government in managing waste to reduce the quantity of waste that can lead to environmental damage. And how to implement regional regulations of DKI Jakarta on waste management in DKI Jakarta.
\end{abstract}

Keywords: Management, garbage, problematica, DKI Jakarta, Government

\begin{abstract}
Abstrak, Persoalan sampah saat ini menjadi persoalan yang membutuhkan perhatian yang lebih bagi dunia. Bagaimana tidak saat ini sampah menjadi penyumbang kerusakan lingkungan terbesar bagi dunia. Dengan adanya hal tersebut maka diperlukan solusi untuk memecahkan persoalan sampah yang menjadi kerusakan lingkungan, salah satunya adalah dengan cara melakukan pengelolaan sampah kembali agar dapat mengurangi kerusakan lingkungan. Seperti halnya yang dilakukan di Indonesia khususnya di Provinsi DKI Jakarta yang seharusnya melakukan pengelolaan sampah yang baik agar dapat mengurangi kerusakan lingkungan yang akan berdampak pada kehidupan masyarakat seperti bencana banjir dan sebagainya. Dalam penelitian ini dibahas bagaimana peran pemerintah DKI Jakarta melakukan pengelolaan sampah untuk mengurangi kuantitas sampah yang dapat mengakibatkan kerusakan lingkungan. Serta bagaimana pengimplementasian peraturan daerah DKI Jakarta tentang pengelolaan sampah di DKI Jakarta.
\end{abstract}

Kata Kunci: Pengelolaan, Sampah, Problematika, DKI Jakarta, Pemerintah 


\section{PENDAHULUAN}

Seiring meningkatnya jumlah penduduk dan pertumbuhan ekonomi di suatu daerah, semakin meningkat pula volume sampah yang dihasilkan. Hal ini disebabkan karena setiap penduduk mulai dari bayi sampai orang tua pasti menghasilkan sisa buangan dari proses aktivitasnya hidupnya seperti makan, masak, mandi, bekerja dan sebagainya.

Disamping itu pola konsumsi masyarakat dan kemajuan teknologi berkontribusi dalam menimbulkan sampah yang semakin beragam, antara lain sampah kemasan yang berbahaya dan sulit diurai oleh alam. Untuk menghadapi trend kuantitas sampah yang terus meningkat, pola pengelolaan sampah masa depan harus berubah. Paradigma pengelolaan sampah yang bertumpu pada pendekatan akhir (end of pipe), yaitu sampah dikumpulkan, diangkut dan dibuang ke tempat pemrosesan akhir (TPA) sudah saatnya ditinggalkan atau diperbaharui karena tidak lagi efektif dan hanya sekedar memindahkan masalah dari rumah ke TPA saja. Sudah saatnya pengelolaan sampah di kota menggunakan trend baru yaitu memandang sampah sebagai sumber daya yang mempunyai nilai ekonomi dan dapat dimanfaatkan, misalnya, untuk energi, kompos, atau bahan baku industri. Paradigma baru pengelolaan sampah memandang bahwa sampah harus ditangani secara komprehensif mulai dari hulu, sebelum dihasilkan suatu produk yang berpotensi menjadi sampah, sampai ke hilir, yaitu pada fase produk sudah digunakan sehingga menjadi sampah, yang kemudian dikembalikan ke media lingkungan secara aman. Pengelolaan sampah dengan paradigma baru tersebut dilakukan dengan prinsip reduce, reuse, dan recycle (3R) (Peraturan Daerah Provinsi DKI Jakarta nomor 3 tahun 2013 tentang pengelolaan sampah). Dengan prinsip 3R volume sampah yang dibuang ke TPA menjadi jauh berkurang dan sampah dapat dimanfaatkan menjadi berbagai produk berguna. Penanganan sampah berbeda-beda disetiap daerah, begitu juga dengan perilaku masyarakatnya. daerah yang berhasil mengelola kebersihan dan lingkungannya dengan baik diberi anugerah yang sudah dikenal luas oleh masyarakat yaitu Penghargaan Adipura. Penghargaan ini merupakan penghargaan lingkungan hidup untuk kota di Indonesia yang dinilai bersih dan teduh (clean and green city) dengan menerapkan prinsip- prinsip Good Governance. Permasalahan sampah erat sekali kaitannya dengan perilaku masyarakat dalam pengelolaan sampah, sebab 
masyarakatlah yang merupakan sumber utama sampah itu sendiri. Mengatasi permasalahan sampah dari sumbernya akan menjadikan permasalahan sampah menjadi lebih sederhana. Di tengah kesulitan dan keterbatasan pemerintah dalam hal penyediaan fasilitas dan sumber daya manusia untuk pengelolaan sampah maka peran masyarakat dalam pengelolaan sampah menjadi aspek yang sangat penting. Berdasarkan uraian diatas peneliti merasa perlu meneliti pengelolaan sampah khususnya untuk mengetahui bagaimana perilaku masyarakat dalam.

Penerapan prinsip-prinsip umum pengelolaan sampah rumah tangga yang baik dan penerapan 3R di Provinsi Daerah Khusus Ibukota Jakarta. Selain itu perlu juga diketahui apa saja kendala yang dihadapi baik oleh masyarakat dan Pemerintah dalam pengelolaan sampah rumah tangga tersebut. Perilaku merupakan proses interaksi antara kepribadian dan lingkungan yang mengandung rangsangan (stimulus), kemudian ditanggapi dalam bentuk respon. Respon inilah yang disebut perilaku. Perilaku ditentukan oleh persepsi dan kepribadian, sedang persepsi dan kepribadian dilatarbelakangi oleh pengalamannya. Perilaku merupakan keadaan jiwa (berfikir, berpendapat, bersikap dan sebagainya) untuk memberikan respon terhadap situasi di luar subjek tertentu. Respon ini dapat bersifat positif (tanpa tindakan) dan bersifat aktif (dengan tindakan) (Umar, 2009). Masyarakat adalah sebuah komunitas yang interdependen (saling tergantung satu sama lain). Umumnya, istilah masyarakat digunakan untuk mengacu sekelompok orang yang hidup bersama dalam satu komunitas yang teratur. Kata "masyarakat" sendiri berakar dari kata dalam bahasa Arab, musyarak. Lebih abstraknya, sebuah masyarakat adalah suatu jaringan hubungan-hubungan antar entitas-entitas (http://id.wikipedia.org/wiki/masyarakat, diakses 1 Mei 2012). Jadi perilaku masyarakat dapat diartikan sebagai respon masyarakat terhadap situasi di luar subjek tertentu.

Lahan Bantargebang telah dimiliki DKI Jakarta sejak tahun 2004. Awalnya kata Said, masyarakat menolak lahan tersebut digunakan untuk tempat pembuangan sampah. Aksi penolakan dan demo besar-besaran pun terjadi menolak keputusan tersebut. "Waktu tahun 2004 saya sebagai wakil rakyat pernah di demo masyarakat Bantargebang yang menolak pemakaian lahan mereka sebagai tempat sampah," ucap Said. Bahkan aksi demo yang sempat berlangsung selama 3 bulan berturut-turut dari masyarakat Bantargebang kata Said sempat membuat gejolak di wilayah Kota Bekasi. 
Gejolak redup, dan masyarakat Kota Bekasi akhirnya menerima karena posisi DKI sebagai ibukota negara serta DKI memperbolehkan masyarakat memanfaatkan lahan. Dan sebagai kompensasi untuk masyarakat sekitar maka DKI Jakarta harus membayar tipping fee. Tangan pertama pengelola Bantargebang sebut Said adalah sebuah PT bernama PBB. PT Godang Tua Jaya baru menjadi pihak ketiga pengelola pada tahun 2009. Pada tahun yang sama, 2009, nama Tempat Pembuangan Sampah (TPS) kemudian diganti menjadi Tempat Pengolahan Sampah Terpadu (TPST) Bantargebang, karena sampah tersebut akan dikelola dan diolah untuk dimanfaatkan kembali serta difasilitasi beberapa teknologi canggih, untuk meminimalisir pencemaran udara di sekitar. Tipping fee masih terus diberikan dan berjalan. Dan terkait tipping fee yang diterima masyarakat disekitar lokasi TPST, hal itu wajar kata Said karena menyangkut dampak adanya sampah disekitar TPST.

Hal ini bisa dilihat bagaimana sebagian besar sampah Jakarta tidak terkelola secara berkelanjutan dan berakhir di tempat pembuangan akhir (TPA) atau tempat pengelolaan sampah terpadu (TPST) Bantargebang Bekasi dalam kondisi memperihatinkan menumpuk secara terbuka (open dumping). Sistem pembuangan sampah secara terbuka tidak lagi diperbolehkan sebagaimana amanat Undang-undang No. 18 Tahun 2008 tentang Persampahan Pasal 29 huruf (e) yang berbunyi, "dilarang melakukan penanganan sampah dengan pembuangan terbuka di tempat pemrosesan akhir”. Larangan menimbun sampah secara terbuka di TPA, mengingat sampah yang ditumpuk dibiarkan terbuka dan membiarkan air lindi (leacheate) tidak terkelola, serta gas methana yang timbul akibat reaksi biokimia sering terjadi ledakan dan kebakaran di TPA. Seperti halnya TPA Bantargebang, TPA jenis ini sangat merusak lingkungan dan menjadi sumber berbagai penyakit, mencemari udara, tanah dan air tanah, mencemari irigasi dan badan-badan air, bau yang meresahkan hingga radius 5-10 km, merusak estetika, penyebab banjir dan krisis air bersih serta potensi konflik sosial. Dari hasil Penelitian Dinas Kesehatan, Dinas kebersihan, dan lingkungan hidup DKI Jakarta (2000), pencemaran di Bantargebang Bekasi tercatat sebagai berikut: (1) 40 persen derajat keasaman air sudah diambang batas, (2) 95 persen ditemukan bakteri Ecoli pada air tanah (bakteri yang bisa menyumbat saluran pernafasan dan pencernaan), (3) 35 persen tercemar Slamonella (virus penyebab tifus), (4) 34 persen foto rontgen ditemukan penduduk positif menderita TBC, (5) 99 
persen warga sekitar bantar Gebang mengalami infeksi saluran pernafasan atas atau ISPA, dan (6) 8 persen penduduk mengalami tukak tulang, bahkan sejumlah warga setempat mengatakan ada beberapa orang yang meninggal sesak nafas akibat asap. Dapat dibayangkan jika 15 tahun yang lalu kondisi lingkungan Bantargebang amat memprihatinkan, bagaimana dengan saat ini, dimana manajemen TPA Bantargebang tidak mengalami kemajuan yang signifikan dalam arti perindungan dan pengelolaan lingkungan Bantargebang.

\section{Kerangka Dasar Teori Implementasi}

Implementasi menurut Van Meter dan Abdul Wahab (2001:65) adalah suatu proses implementasi sangat dipengaruhi oleh sifat kebijakan yang akan dilaksanakan. Perubahan, kontrol dan kepatuhan bertindak merupakan konsep-konsep penting dalam prosedur implementasi. Sedangkan menurut Mazmanian dan Sabatier (dalam Widodo 2009:88) memaparkan bahwa implementasi adalah pelaksanaan keputusan dasar, biasanya dalam bentuk undang-undang, namun dapat pula berbentuk perintahperintah atau keputusan- keputusan eksekutif yang penting atau keputusan badan peradilan. Sedangkan menurut Ripley dan Franklin (dalam Winarno, 2012:148) berpendapat bahwa implementasi adalah apa yang terjadi setelah undang-undang ditetapkan yang memberikan otoritas program, kebijakan, keuntungan, atau suatu jenis keluaran yang nyata.

\section{Pengelolaan Sampah}

Pengelolaan sampah menurut Noelaka (2008) berpendapat bahwa pengelolaan sampah merupakan upaya menciptakan keindahan dengan cara mengolah sampah yang dilaksanakan secara harmonis antara rakyat dan pengelola atau pemerintah secara bersama-sama. Lalu menurut Alex (2012) pengelolaan sampah merupakan kegiatan yang meliputi pengumpulan, pengangkutan, pemrosesan, pendauran ulang, atau pembuangan dari material sampah.

\section{Metode Pengelolaan Sampah}

Pengelolaan sampah merupakan suatu aktivitas dimana sampah diubah menjadi sesuatu yang berguna atau digunakan untuk suatu aktivitas lain yang membutuhkan sampah yang masih bisa digunakan. Menurut Noelaka (2008) 
berpendapat bahwa pengelolaan sampah merupakan upaya menciptakan keindahan dengan cara mengolah sampah yang dilaksanakan secara harmonis antara rakyat dan pengelola atau pemerintah secara bersama- sama. ${ }^{10}$ Pengelolaan sampah dibutuhkan untuk menciptakan lingkungan hidup yang baik, dan juga berfungsi untuk masyarakat bisa untuk menjaga lingkungan hidup agar tetap terjaga, dikarenakan masih banyak masyarakat umum di Indonesia mengelola sampah itu dengan hanya menimbun dan membiarkan sampah di suatu tempat sehingga sampah tersebut semakin lama semakin menumpuk, selain itu juga masih banyak juga masyarakat yang mengelola sampah secara tidak bertanggung jawab seperti membuang sampah tersebut ke suatu sungai sehingga menyebabkan sungai tersebut menjadi tercemar dan terhambat alirannya oleh adanya sampah yang dibuang tersebut, serta masih banyak juga masyarakat yang mengelola sampah dengan cara membakar sampah tersebut yang mengakibatkan udara menjadi tidak sehat bagi orang-orang sekitarnya. Terlebih lagi masyarakat yang berada di DKI Jakarta yang merupakan salah satu daeerah di Indonesia yang memiliki mobilitas tinggi dan merupakan salah satu Provinsi di Indonesia memiliki penduduk yang paling banyak di antara daerah-daerah di Indonesia lainnya. Dengan adanya mobilitas dan jumlah penduduk yang masif di DKI Jakarta pasti tidak dapat dihindarkan dari kebutuhan akan sesuatu hal yang pastinya kebutuhan tersebut akan menjadi sampah yang menjadi salah satu problematika di DKI Jakarta.

Dalam pengelolaan sampah terdapat prinsip-prinsip pengelolaan sampah yang tidak asing sering kita dengar yaitu prinsip 3R (reduce, reuse, dan recycle) yang dimana prinsip tersebut mampu untuk mereduksi sampah yang akan dibuang ke tempat pembuangan akhir (TPA). 1) Prinsip reduce merupakan prinisp dimana sebisa mungkin penggunaan dalam pemakaian barang yang tidak akan menyebabkan masifnya tingkat produktifitas penghasilan sampah sehingga diharapkan tidak menimbulkan pertambahan sampah yang signifikan. Dari kata "reduce" yang berarti mengurangi diartikan sebagai pengurangan produksi sampah dengan tidak menggunakan atau mengonsumsi suatu benda yang akan menjadi sampah. Prinsip ini membantu kita untuk menjaga kelestarian lingkungan hidup dengan cara seperti berbelanja ke minimarket dengan membawa keranjang elanja sendiri sehingga tidak memerlukan plastik untuk membawa atau meletakkan belanjaan tersebut, jadi tidak 
akan menimbulkan pertambahan produksi sampah. Selain membawa keranjang sendiri dalam berbelanja, yaitu penggunaan lap kain sebagai pengganti tissu merupakan kegiatan yang juga mampu untuk mereduksi pertambahan sampah dan menjaga lingkungan hidup tetap lestari, karena bahan baku dari tissu sendiri terbuat dari serat kayu yang pastinya membutuhkan pohon yang sangat banyak untuk membuat tissu tersebut. Serta kegiatan mengumpulkan barang bekas yang selanjutnya dijual ke pengumpul atau lapak dapat membantu untuk mengurangi pertumbuhan produksi sampah serta memberikan nilai ekonomis terhadap masyarakat yang mengerapkan prinsip reduce ini. 2) Prinsip reuse merupakan prinsip dimana barangbarang yang kemungkinan masih bisa digunakan untuk dipergunakan kembali dalam sesuatu hal. Seperti penggunaan botol yang sudah tidak terpakai lalu dijadikannya botol tersebut menjadi sesuatu hal yang berharga seperti dijadikan pot untuk menanam tanaman yang diletakkan di sekitar halaman rumah. Selain itu, penggunaan dalam pemakaian kaleng bekas yang digunakan untuk suatu hal, juga mampu untuk mengurangai produksi sampah. Serta penggunaan kantong plastik secara terusmenerus, seperti penggunaan kantong plastik untuk membawa atau meletakkan barang belanjaan ketika sedang berbelanja, atau dengan dijadikannya kantong plastik tersebut sebagai wadah untuk menempatkan benda-benda yang terdapat di rumah. 3) Prinsip recycle yaitu prinsip dimana barang yang sudah tidak terpakai dirubah ke barang yang memiliki kegunaan dan nilai ekonomis yang bermanfaat bagi masyarakat. Semisal limbah plastik yang di daur ulang menjadi keranjang yang terbuat dari plastik yang berguna bagi masyarakat serta memberikan nilai ekonomis terhadap masyarakat. Serta melakukan daur ulang terhadap limbah kertas yang sudah tidak terpakai yang dirubah menjadi kertas baru dengan menggunakan teknologi mesin daur ulang kertas yang dimana mesin tersebut menjadikan limbah kertas menjadi bubur kertas lalu diproses sehingga menjadi kertas kembali yang bisa digunakan kembali tanpa perlu membuat kertas yang baru dengan merelakan pohon yang ditebang dan mampu menekan peningkatan produksi sampah serta mampu menjaga kelestarian lingkungan hidup.

Selain prinsip 3R tersebut terdapat satu prinsip lain, namun prinsip ini masih baru dalam prinsip mengenai pengelolaan sampah, prinsip tersebut yakni replace, mengganti dengan yang lebih ramah lingkungan, mengganti barang yang sering 
digunakan dengan sifat sekali pakai dengan barang yang dapat dipakai tahan lama. Seperti menggunakan botol minum dari bahan plastik yang dikhususkan untuk bisa dipakai berulang-ulang, atau dari bahan alumunium. Serta mengganti kantong plastik dengan keranjang, atau tas kain, atau dari bahan daur ulang untuk berbelanja.

Dalam pengelolaan sampah terdapat cara-cara bagaimana sampah tersebut ditangani dan diolah. 1) Penumpukan (dumping) cara ini adalah cara yang sering dipakai di negara berkembang dan khususnya digunakan juga di DKI Jakarta, cara ini merupakan cara dimana sampah hanya di timbun atau dibiarkan dibuang ke suatu tempat atau lahan. Metode ini merupakan metode yang tidak baik dalam pengelolaan sampah, dikarenakan metode tersebut sangat berdampak besar bagi lingkungan yang sekitarnya yang dijadikan sekitar lingkungan tersebut menjadi tumpukan sampah. Seperti menimbulkan bau yang menyengat, menimbulkan penyakit, dan pencemaran air pemukiman dan air tanah oleh air lindi akibat terbilasnya timbunan sampah oleh air hujan. Metode ini masih di terapkan oleh DKI Jakarta yang menyebabkan terjadinya problematika pengelolaan sampah di DKI Jakarta. 2) Pengomposan (composting) adalah cara dimana sampah-sampah dijadikan pupuk kompos yang berguna bagi masyarakat dan menguntungkan bagi masyarakat. 3) Sanitasi dalam tanah (sanitary landfill) merupakan cara pengolahan sampah yang cukup baik dilakukan denganmenempatkan sampah di dalam tanah kemudian menutup kembali sampah tersebut dengan tanah. Apabila semua sampah diproses dengan metode ini maka akan memerlukan tanah yang sangat luas. Oleh karena itu, sampah diproses adalah sampah yang benar-benar tidak dapat dimanfaatkan untuk keperluan apapun. ${ }^{13}$ Dari metode-metode tersebut tidak ada yang mampu mengatasi keseluruhan permasalahan sampah yang berada di DKI Jakarta dengan tetap menjaga kelestarian lingkungan hidup yang tanpa melakukan pencemaran air, darat maupun udara. Meskipun metode-metode yang ada untuk mengelola sampah kurang efektif dalam pengurangan permasalahan/problematika sampah yang ada khususnya di DKI Jakarta, dengan menggunakan prinsip 3R tersebut dapat membantu mengurangi permasalahan sampah yang ada di DKI Jakarta tanpa khawatir terjadinya kerusakan lingkungan hidup. 


\section{METODE PENELITIAN}

Penelitian yang digunakan pada penelitian ini adalah metode penelitian yang menggunakan studi literatur yang dimana dalam pengumpulan data menggunakan sumber- sumber Pustaka dan dokumentasi-dokumentasi penelitian yang sudah dipublikasi maupun belum dipublikasi. Data-data penelitian tersebut diakumulasikan serta dilakukan kajian dan analisis yang mendalam agar dapat dijadikan sumber data dalam penelitian ini.

\section{PEMBAHASAN}

\section{Peran Pemerintah Daerah dalam Pengelolaan Sampah}

Sampah kota diartikan sebagai sampah yang dibuang oleh masyarakat kota. Permasalahan sampah kota adalah volume sampah besar dan melebihi daya tampung tempat pembuangan akhir (TPA). Lahan TPA semakin sempit, faktor jarak mengakibatkan mengangkut sampah kurang efektif, teknologi pengolahan sampah tidak optimal, terbatasnya tempat penampungan sampah sementara (TPS), kurangnya sosialisasi dan dukungan pemerintah mengenal pengelolaan sampah, minimnya edukasi dan manajemen diri mengenai pengolahan sampah, dan manajemen sampah tidak efektif. Pengolahan sampah di Jakarta masih mengandalkan peran pemerintah. Petugas kebersihan mengambil sampah dari penduduk dan membawa sampah ke TPS untuk diangkut ke TPA oleh dinas kebersihan. Persentasi masyarakat yang dilayani di Jakarta masih sangat tinggi, berarti peran serta masyarakat masih rendah. Di Jakarta mulai dilakukan pemberdayaan masyarakat dalam mengelola sampah untuk mengatasi sampah. Pengelolaan sampah ditujukan untuk melestarikan fungsi lingkungan hidup. Dalam Undang-undang tentang pengelolaan lingkungan hidup pasal 1 ayat 1 dijelaskan bahwa "Lingkungan hidup merupakan adalah kesatuan ruang dengan semua benda, daya, keadaan, dan makhluk hidup, termasuk manusia dan perilakunya, yang mempengaruhi kelangsungan perikehidupan dan kesejahteraan manusia serta makhluk hidup lain". Dan pada pasal 1 ayat 5 dijelaskan bahwa "Pelestarian lingkungan hidup adalah rangkaian upaya untuk memelihara kelangsungan daya dukung dan daya tampung lingkungan hidup". Pemerintah memiliki peranan yang sangat besar terhadap pengelolaan sampah yang menjadi problematika saat ini. Pemerintah memiliki peran mengenai pengelolaan sampah 
yakni pemerintah membuat kebijakan mengenai pengelolaan sampah, membuat program persuasif agar masyarakat mau ikut berpartisipasi aktif dalam pengelolaan sampah tersebut serta mendorong dan memfasilitasi aktivitas masyarakat yang peduli terhadap lingkungan hidup dengan melakukan pengelolaan sampah secara terpadu.

Dalam Peraturan Daerah Provinsi Daerah Khusus Ibukota Jakarta nomor 3 tahun 2013 tentang pengelolaan sampah pada BAB III pasal 4 tentang Tugas dan Wewenang menjelaskan bahwa pemerintah memiliki peran dalam pengelolaan sampah sebagai berikut :

a) menumbuhkembangkan dan meningkatkan kesadaran masyarakat dan pelaku usaha dalam pengelolaan sampah; b) mengalokasikan dana untuk pengelolaan sampah; c) melakukan penelitian, pengembangan teknologi pengurangan dan penanganan sampah; d) melaksanakan, memfasilitasi, dan mengembangkan upaya pengurangan dan penanganan sampah; e) memanfaatkan, memfasilitasi, dan mengembangkan hasil pengolahan sampah; f) mengelola sampah dan memfasilitasi penyediaan prasarana dan sarana pengolahan sampah; g) memanfaatkan dan memfasilitasi penerapan teknologi pengolahan sampah yang berkembang pada masyarakat untuk mengurangi dan/atau menangani sampah; dan h) mengoordinasikan antar lembaga pemerintah, masyarakat, dan pelaku usaha agar terdapat keterpaduan dalam penjelasan Undangundang tentang pengelolaan lingkungan hidup pasal 1 ayat 1 dan 5 pengelolaan sampah. Peran Pemerintah tersebut sangatlah membantu dalam kemudahan pencapaian terwujudnya lingkungan hidup yang sehat dan bersih dari sampah. Walaupun demikian tujuan tersebut tidak akan tercapai apabila tidak ada peran serta dari seluruh pihak yang membantu peran dari Pemerintah.

\section{Pengimplementasian Kebijakan Mengenai Pengelolaan Sampah.}

Kebijakan Pemerintah Daerah DKI Jakarta mengenai pengelolaan sampah yang terdapat dalam peraturan daerah Provinsi DKI Jakarta nomor 3 tahun 2013 belum keseluruhan diimplementasikan baik dari pihak Pemerintah sendiri maupun dari pihak masyarakat. Dari pihak Pemerintah Daerah DKI Jakarta sendiri dapat kita lihat dari teknologi yang semestinya digunakan dalam pengelolaan sampah tersebut sampai saat ini belum memadai sehingga menyebabkan pengelolaan sampah tidak optimal. Serta kurangnya Pemerintah dalam mengalokasikan dana terhadap pihak- 
pihak yang concern terhadap kelestarian lingkungan hidup sehingga pihak-pihak tersebut dengan susah payah mencari dana untuk membeli sarana dan prasarana sendiri yang digunakan untuk pengelolaan sampah tersebut. Dari pihak masyarakat sendiri masih banyak masyarakat yang menghiraukan kebijakan pemerintah daerah dengan masih adanya kegiatan yang menentang kebijakan mengenai pengelolaan sampah tersebut seperti masih banyaknya masyarakat membuang sampah sembarangan, seperti membuang sampah ke aliran sungai yang mengakibatkan sungai tersebut menjadi tercemar dan terhambat. Belum terimplementasinya kebijakan tersebut diakibatkan oleh kurang tegasnya pemerintah dalam memberikan sanksi terhadap masyarakat yang melanggar kebijakan tersebut. Kurangnya sosialisasi Pemerintah terhadap kebijakan tersebut. Serta kurangnya pemahaman masyarakat mengenai kebijakan tersebut.

\section{SIMPULAN}

Sampah merupakan salah satu problematika yang terdapat di seluruh dunia. Pembangunan negara yang merupakan tujuan negara-negara dunia pasti akan berdampak pada kerusakan lingkungan yang diakibatkan oleh sampah yang ditimbulkan oleh adanya aktivitas pembangunan yang dilakukan oleh manusia. Menyadari setiap hari terjadi pencemaran dan/atau perusakan lingkungan hidup, baik yang diakibatkan karena proses alam maupun yang diakibatkan oleh pembangunan melalui aktivitas manusia, maka hampir semua negara mempunyai keinginan bagaimana agar pembangunan berjalan tanpa merusak atau mencemari lingkungan hidup. Khususnya di Daerah Khusus Ibukota Jakarta yang merupakan pusat pembangunan yang ada di Indonesia. Pastinya di Daerah Khusus Ibukota Jakarta yang memiliki mobilisasi yang sangat besar tidak dapat dihindarkan dari penggunaan suatu barang yang nantinya barang tersebut akan menjadi sampah. Hal itu lah yang menjadikan problematika pengelolaan sampah Pemerintah DKI Jakarta. Seperti sudah dijelaskan dalam pendahuluan bahwa pengelolaan sampah di DKI Jakarta pada saat ini masih dominan menggunakan metode open dumping atau penimbunan sampah di suatu tempat sehingga menghasilkan bukit sampah yang semakin lama semakin membesar. Metode tersebut kurang baik diterapkan karena akan memberikan dampak yang buruk bagi masyarakat. Untuk mencegah hal itu terjadi Pemerintah memberikan sosialisasi yang kuat tentang prinsip-prinsip pengelolaan sampah yakni prinsip 3R 
(reduce, reuse, dan recycle). Dengan adanya prinsip tersebut yang disosialisasikan dan dengan harapan keseluruhan masyarakat mau untuk menerapkan prinsip tersebut maka dengan adanya hal itu mampu menekan peningkatan produksi sampah yang signifikan. Seperti sudah diketahui pengelolaan sampah di DKI Jakarta sudah diatur dengan sebaik mungkin dalam Peraturan Daerah DKI Jakarta nomor 3 tahun 2013 tentang pengelolaan sampah. Namun kebijakan tersebut belum terimplementasi dengan baik dikarenakan kurangnya pemerintah dalam memberikan sosialisasi dan edukasi tentang pengelolaan sampah kretifitas; kurangnya pembinaan oleh Pemerintah sehingga alat-alat daur ulang sampah yang difasilitasi pemerintah masih belum dipergunakan secara optimal; masih kurangnya kesadaran dan minat masyarakat untuk memilah dan memisahkan sampah rumah tangga mereka sehingga sampah mereka akan terus berujung ke TPA; serta minimnya dana penganggaran sarana dan prasarana penunjang daur ulang sampah. Sampah merupakan permasalahan yang kompleks, khususnya di DKI Jakarta. Untuk mengurangi permasalahan peningkatan produksi sampah perlu diterapkannya metode pengelolaan sampah yang baik dan perlunya kerjasama antara pemerintah dan masyarakat dalam melakukan kegiatan pengelolaan sampah serta merubah perilaku buruk masyarakat yang dimana perilaku masyarakat sekarang ini masih membuang sampah seenaknya, perilaku tersebut dirubah dengan menerapkan prinsip pengelolaan sampah yakni prinsip 3R.

\section{DAFTAR PUSTAKA}

Daniel, Valerina. 2009. Easy Green Living. Jakarta: Mizan Publika.

Habsari, Rizki Dwi. 2016. “Implementasi Peraturan Daerah Nomor 2 Tahun 2011 Tentang Pengelolaan Sampah di Kelurahan Karang Anyar Kecamatan Sungai Kunjang Kota Samarinda”. eJournal Ilmu Pemerintahan, Vol. 4, No. 1, hlm. 282-293.

Hidayat, Putra Tri. 2012. "Kebijakan Tentang Pengelolaan Sampah”. Skripsi. Jurnal Kesehatan Masyarakat, Vol. 8, No. 8, hlm. 404-410.

Mulasari dkk. 2014. "Kebijakan Pemerintah dalam Pengelolaan Sampah Domestik”. Pustaka Pelajar. 2007. Undang-undang Pengelolaan Lingkungan Hidup. Yogyakarta. 
Rahman, Adi. 2013. "Perilaku Masyarakat dalam Pengelolaan Sampah Rumah Tangga”. Jurnal Bina Praja, Vol. 5, No. 4, hlm. 215-220.

Supriadi. 2008. Hukum Lingkungan di Indonesia. Jakarta: Sinar Grafika. Surakarta: Universitas Sebelas Maret.

Tim Redaksi Nuansa Aulia. 2008. Himpunan Peraturan Perundang-undangan Tentang Analisis Mengenai Dampak Lingkungan. Bandung.

\section{Website:}

gobekasi.pojoksatu.id/2015/10/27/ini-dia-sejarah-akhirnya-bantargebang-dikuasai sampah-dki-jakarta/

http://id.wikipedia.org/wiki/masyarakat

http://www.ebookpp.com/pe/pembahasansampah-doc.html

https://media.neliti.com

https://www.google.com/amp/s/ayodarling.wordpress.com/2013/04/07/pengelolaansampah/amp/

kedaipena.com/kompleksnya-permasalahan-sampah-di-jakarta-1/

\section{Sumber Lain:}

Badan Pengendalian Lingkungan Hidup DKI Jakarta. 2013. Pedoman Pemberdayaan Masyarakat dalam Mengelola sampah. Jakarta: Terbitan Badan Pengendalian Lingkungan Hidup DKI Jakarta dan URDI.

Penelitian Dinas Kesehatan, Dinas Kebersihan, dan Dinas Lingkungan Hidup DKI Jakarta (2000).

Penjelasan Undang-undang tentang pengelolaan lingkungan hidup pasal 1 ayat 1 dan 5 .

Peraturan Daerah Provinsi Daerah Khusus Ibukota Jakarta Nomor 3 Tahun 2013 Tentang Pengelolaan Sampah

Undang-undang nomor 18 tahun 2008 tentang persampahan.

Undang-undang Tentang Pengelolaan Lingkungan Hidup. 